
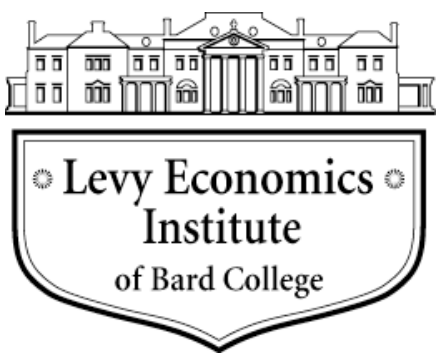

Working Paper No. 789

\title{
Full Employment: The Road Not Taken
}

by

\author{
Pavlina R. Tcherneva \\ Levy Economics Institute of Bard College
}

March 2014

The Levy Economics Institute Working Paper Collection presents research in progress by Levy Institute scholars and conference participants. The purpose of the series is to disseminate ideas to and elicit comments from academics and professionals.

Levy Economics Institute of Bard College, founded in 1986, is a nonprofit, nonpartisan, independently funded research organization devoted to public service. Through scholarship and economic research it generates viable, effective public policy responses to important economic problems that profoundly affect the quality of life in the United States and abroad.

Levy Economics Institute

P.O. Box 5000

Annandale-on-Hudson, NY 12504-5000

http://www.levyinstitute.org

Copyright (C) Levy Economics Institute 2014 All rights reserved 


\begin{abstract}
It is common knowledge that John Maynard Keynes advocated bold government action to deal with recessions and unemployment. What is not commonly known is that modern "Keynesian policies" bear little, if any, resemblance to the policy measures Keynes himself believed would guarantee true full employment over the long run. This paper corrects this misconception and outlines "the road not taken"; that is, the long-term program for full employment found in Keynes's writings and elaborated on by others in works that are missing from mainstream textbooks and policy initiatives. The analysis herein focuses on why the private sector ordinarily fails to produce full employment, even during strong expansions and in the presence of strong government action. It articulates the reasons why the job of the policymaker is, not to "nudge" private firms to create jobs for all, but to do so itself directly as a matter of last resort. This paper discusses various designs of direct job creation policies that answer Keynes's call for long-run full employment policies.
\end{abstract}

KEYWORDS: Unemployment as a Monetary Phenomenon; Long-run Full Employment; John Maynard Keynes; Social Economy; Aggregate Demand Management

JEL CLASSIFICATIONS: B3, E2, E6, H1, H31, J68 


\section{INTRODUCTION}

It is understood in mainstream economics that true full employment is neither possible nor desirable. It is not possible due to automation, outsourcing, and other structural shifts in the economy that prevent the market from creating jobs for all who want them. It is undesirable because, even if the government tried to create an adequate number of jobs when the market failed, a pesky inflation problem would cause more harm to the economy than the good those extra jobs would bring. Hence economists consider some NAIRU (non-accelerating inflation rate of unemployment) level of unemployment to be the most one could hope for. The new NAIRU in the U.S. has been placed as high as $6.7 \%$ in recent years (Weidner and Williams 2011), which translates into well over 10 million jobless individuals today who want to be part of the productive workforce but are trapped in forced idleness.

The peculiar problem in economics is that policies that would generate and maintain tight full employment over the long run have rarely been tried. "Tight full employment" here is defined as a situation where a job offer at a basic living wage-benefit package is available to anyone who wants one. This is the condition that Nobel Prize winning economist William Vickrey called "chock full employment" (Vickrey 1994), and the great British social reformer William Beveridge identified as the existence of slightly more vacancies than there are job seekers (Beveridge 1944). But the economist who taught us how it could be achieved over the long run was John Maynard Keynes, for whom full employment was a condition of less than 1\% of peacetime unemployment (Keynes 1980: 303, emphasis added).

It is common knowledge that Keynesian stimuli are frequent policy tools to deal with recessions and unemployment; what is not commonly known is that modern "Keynesian policies" bear little, if any, resemblance to the policy measures Keynes himself believed would guarantee true full employment over the long run. This chapter aims to correct this misconception and outlines "the road not taken," i.e., the long-term program for full employment found in Keynes's writings and elaborated on by others in works that are missing from mainstream textbooks and policy initiatives. 


\section{KEYNES'S FULL EMPLOYMENT SOLUTION: A REINTERPRETATION}

In a money-using market economy, unemployment is a monetary phenomenon, meaning there are people ready, willing, and able to work for wages, but no wage offers are forthcoming. From a firm's point of view, it means that the cost of hiring a jobless individual is not compensated by enough revenue and profit to justify the offer of employment. Unemployment as a monetary phenomenon exists irrespective of whether the economy is booming or contracting. Even in prosperous times, there are always individuals looking for wage work, and who employers consider unemployable for one reason or another. Either business conditions (in an already strong economy) do not guarantee any further increase in demand to warrant hiring them, or employers use some other individual characteristic to turn prospective employees away. This would be the case when the jobless belong to groups that some employers consider least favorable, such as at-risk youth, the formerly incarcerated, the long-term jobless, stay-at-home moms, minorities, and others. "It isn't really the business of private individuals," Keynes argued, "to spend more than they naturally would, any more than it is their business to provide for the unemployed by private charity" (Keynes 1982: 151).

The private sector cannot be counted on to guarantee full employment even in good times. And when economies decelerate and enter recessions, the situation naturally becomes worse: not only is demand inadequate to warrant hiring all who wish to work at the peak of the cycle, but once it decelerates and starts declining, mass layoffs are prompted. Joblessness for Keynes was "an infectious illness, [which] multiplies itself and spreads from house to house unless something is done to check it" (Keynes, 1981: 824). It is not only "an evil that is in the homes of the unemployed themselves" (ibid.), but one that affects others, as every person who is unemployed puts another one out of work due to the loss of purchasing power. Furthermore, unemployment breeds unemployability. Paradoxically, the mark of unemployment is itself an obstacle to obtaining a job. In the eyes of the employer, forced idleness even for a short period of time makes hiring the jobless a risky proposition due to the loss of skill. For example, nine months of joblessness translates into shaving off four years of work experience (Eriksson and Rooth, forthcoming).

In the postwar era, governments have implemented various policies that put a floor on collapsing demand via countercyclical spending. "Priming the pump" is the catchall phrase for what is popularly but inaccurately referred to as the "Keynesian" solution to joblessness. All 
that is required in recessions, according to the conventional view, is for the government to spend more when the private sector spends less and unemployment would recover. But governments should be especially careful not to provide additional demand to the economy in prosperous times, as that would only cause prices to increase. In other words, mainstream thought considers priming aggregate demand to be effective only as a depression solution (Krugman 1999). But because unemployment has remained stubbornly high five years after the 2008 Global Financial Crisis, and despite aggressive government action, faith in the effectiveness of Keynesian policies even during recessions has once again waned.

This love-and-hate relationship with Keynesian economics will continue so long as modern economies move through big business cycle swings necessitating government action, and policymakers continue to employ measures that are relatively weak and marginally effective. A new approach to fiscal policy is needed - a road to full employment not yet takenthat is rooted firmly in the original contributions of Keynes, rather than those of the conventional pump priming approach associated with the Neoclassical synthesis and revived by the New Economic Consensus.

The latter places excessive focus on the aggregate level of government spending and relatively little on the specific type or direction of spending. The argument has been that, so long as public spending greases the economic wheels, and spurs growth and investment, job creation will naturally follow. For Keynes, by contrast, it was the manner of spending that was more important to ensure that a recovery was strong and full employment was sustained — a direct employment approach was superior to all other alternatives.

Keynes had a very specific vision of what this direct employment approach would look like and offered deep theoretical, methodological, and policy arguments for its advantages over priming the pump (more below). His rationale was not embraced by the profession in large part because of a mistaken conflation of Keynes's concept of "effective demand" with the concept of "aggregate demand." Aggregate demand is the summation of all current expenditures at current prices in any given accounting period by all sectors (household, firm, foreign, and public). It reflects the level of GDP, whereas effective demand is the amount of hiring that takes place based on a firm's expected future costs and profits that would justify that level of hiring today. Note that an economy could have very strong aggregate demand (booming GDP) and still experience deficient effective demand, meaning that future expected costs and profits may be such that firms would be discouraged from hiring everyone who is ready, willing, and able to 
work. In other words, the point of effective demand may still be below its full employment level, even when total spending in the economy is strong.

According to Keynes, pumping more spending into the economy does not necessarily generate enough job growth to bring the economy to full employment - it all depends on the employment elasticity of demand. At the macro-level, a dollar spent is a dollar earned, but any windfall to households and firms that would result from strong government spending need not generate additional employment-creating demand. The new income could go towards the repayment of debt (deleveraging), the accumulation of savings (thrift), or translate into higher prices for products in sectors with strong capacity utilization (instead of expanding output). In a strong economy, the price effect, Keynes explained, was particularly prominent and important, as it skewed the income distribution from wages to profits (Keynes 1964 [1936]: 287).

Securing jobs for all who wanted to work was a crucial policy goal nonetheless. Although the economy was booming, it became no less urgent to provide the means to a livelihood to those who still remained unemployed. For Keynes, the purpose of economic policy at all stages of the business cycle was to solve the "real problem, fundamental yet essentially simple ... [namely] to provide employment for everyone" (Keynes 1980: 267).

What was needed was to ensure that the point of effective demand is always at a level consistent with full employment. But policy makers had no tools at their disposal to fix firm expectations of future costs and returns over the long run at a level that would induce them to provide jobs for all workers on an ongoing basis. Governments could try to fine-tune interest rates, change discretionarily and counter-cyclically their level of spending over the business cycle, or they could use redistributive policies to manage the level of private consumption and investment. And while all of these measures would have an impact on firm expectations (and hence on effective demand), they could never guarantee that the level of firm hiring would be consistent with full employment, except by accident.

Because affixing expectations was an impossible task, the job of the policy maker was not to "nudge" the private sector to create jobs for all, but to do so itself as a matter of last resort. Though governments ought to design policies that ensure a strong and resilient private sector, when full employment was concerned, Keynes argued, it was the job of the public sector to provide work opportunities for those whom the private sector left behind.

In other words, it was the task of the public sector to provide jobs for all and, to this end, the direction of spending mattered. The solution was not fine-tuning or pump-priming, but 
direct job creation for those who wished to work. And while many think of public works as the Keynesian solution to depressions, Keynes was steadfast-direct employment is to be undertaken in good times as well. A discontinuation of public works in conditions of private sector overcapacity is undesirable, as the latter cannot expand to absorb the workers who have been laid off from the public sector (Keynes 1982: 150).

It is more appropriate to think of Keynes's full employment policy as one of "on-thespot" or direct employment of the unemployed at any stage of the business cycle (Tcherneva 2012a). In boom times, Keynes argued we are "more in need . . . of a rightly distributed demand than of greater aggregate demand" (Keynes 1982: 395). His blueprint for full employment over the long run was "to take the contract to the worker and distressed areas and regions." This was to be done in good times or bad. Public works are not to be undertaken as stop-gap measures, but as preventative solutions: "the problem of bringing the work to the men [sic]. . should be regarded as a continuing one" (Keynes 1980: 331). Fiscal policy today pays little attention to the prevention of unemployment and places all emphasis on the cure. Considering the severe and multiplicative effects once joblessness develops, modern policy works in a way that is always too late.

A permanent policy of direct hiring for those who want to work but have not found jobs in the private sector would secure true full employment at every stage of the business cycle. The question then would be how the policy maker could ensure that this approach would not be inflationary? Minsky's reinterpretation of Keynes's on-the-spot employment approach provides the answer. An Employer of Last Resort (ELR) program would "take workers as they are" and "fit the job to the worker," thus securing full employment over the long run (Minsky 1986). Through the ELR, the government would ensure that there is an infinitely elastic demand for labor by divorcing the offer of employment from the profitability of employment at the margin. This policy would establish a basic decent wage-benefit package that would provide an anchor to inflation. The mechanism would be as follows: as the economy grows and experiences inflationary pressures, the public sector ELR pool would shrink, thus reducing the government's contribution to aggregate demand. In other words, it would have a deflationary effect that alleviates the inflationary tendencies in the private sector. Conversely, when the economy slides into a recession and workers are laid off en masse, the deflationary environment would be countered by the expanding public sector spending on employing the unemployed into the ELR pool. Once the economy begins to recover, private employers can hire public sector workers at a 
premium above the fixed ELR wage. The wage is not to be indexed to inflation (but would be changed periodically and discretionarily) and would not compete with wages in the private sector. As such, it would serve as the effective minimum wage in the economy and would provide a stable floor to demand. Because the ELR program offers a stable anchor to wages and a countercyclical spending mechanism, the program itself is designed to offset rather than contribute to inflationary pressures. As it is the case today, inflation from other sources is still possible, e.g., from private sector credit expansion, supply shocks, speculative euphoria, or any other component that contributes to the rising markup of prices. But the ELR program itself (unlike priming the pump) is not one of them. ${ }^{1}$

An additional and important feature of the ELR program is that it does not exacerbate income inequality the way conventional pump priming does today. Instead, it improves it. Proinvestment, pro-growth aggregate demand management usually creates job opportunities for the high-wage, high-skilled employable workers first - precisely those who are in high demand by the private sector and do not face serious and lasting unemployment problems. By contrast, workers who are last hired and first fired usually come from the bottom of the income distribution and experience the most precarious labor market conditions and longest spells of unemployment. They do not benefit directly from the job creation effect of pump priming policies. The expectation is that demand for high-wage workers would trickle down in the form of demand for the products produced by low-wage workers. Modern pump priming policies offer very few direct employment initiatives for those at the bottom of the income distribution who experience vicious employment cycles.

It is no surprise then that priming the pump can feed inflationary tendencies in a booming economy: governments compete with the private sector for the same highly skilled workers that are in short supply. Greater and greater government expenditures would be needed to push more growth and lower unemployment further. But such a pro-growth pro-investment approach only feeds the profits and wages at the top of the income distribution, thus exacerbating inequality within-labor and between labor and capital. Priming the pump is not Keynes's solution to full employment because it worsens inflation and income inequality and

\footnotetext{
${ }^{1}$ The impact of the ELR program on the mark-up has been modeled in Tcherneva (2012b) using a simple KaleckiMinsky model. The paper also compares this impact to those from other conventional income support or progrowth, pro-investment policies such as unemployment insurance, investment subsidies, or government contracts with guaranteed profits to firms. None of these programs exhibit the countercyclical and price stabilization features of the ELR program.
} 
does not guarantee tight full employment. These key problems with the aggregate management approach were clearly identified by Keynes in chapter 20 of the General Theory, but the economics profession paid no heed.

Keynes's solution, by contrast, was direct job creation for the unemployed and in areas that experienced difficulties even in good times. An on-the-spot employment program for all who wish to work at a base wage would provide an effective floor to demand and wages in the economy while securing true full employment over the long run. By stabilizing wages and incomes of those at the bottom of the income distribution (rather than those at the top), such a policy would not erode the income distribution. And by establishing a genuine wage floor for the economy as a whole, the income distribution would actually be improved. Because full employment is guaranteed by policy design, and does not rely on ever-increasing aggregate demand and firm profits for job creation, the policy itself does not worsen income inequality as modern policies do. Finally, if the program contains an ELR buffer stock mechanism (a fixedwage labor pool that expands in recessions and contracts in expansions), it can also have an internal price-stabilizing feature for the entire economy that is not observed in modern aggregate demand management.

The neoclassical pump-priming approach is upside down; it targets growth and sees job creation as a byproduct. When the desired employment effect does not materialize, jobless recoveries are rationalized as the natural outcome of modern globalized and automated economies. This has little to do with Keynes's prescriptions. For Keynes, employment was the primary task of the policy maker and growth was a byproduct of a pro-employment policy. With a permanent on-the-spot employment program, jobless recoveries are eliminated by definition.

A final word on why Keynes objected to the early aggregate demand management models - a critique still relevant today. For methodological and practical reasons, it was not possible to close the gap between current and potential output. Because GDP did not account for the number of people employed in the production of goods and services it measured, one could not tell what the impact on employment would be from a change in demand for product. In other words, GDP may be growing and employment may be falling if demand were directed to more capital-intensive production. Though Keynes assumed a stable output/employment ratio in some of his theoretical work, as a practitioner and a policy man, he argued that this was not a useful assumption and that producing a certain growth rate would not necessarily translate into a specific employment outcome (as it was later stipulated by Okun's law). To claim that a 
measure of "potential output" somehow measured a fully employed economy was especially problematic, because it did not account for the new entrants into the labor market, population growth, or any dynamic changes in the labor/capital composition of output. Any measure of "potential output" that did not explicitly account for the number of men and women wishing to engage in paid employment was an "impostor" (Keynes 1980: 72).

For theoretical, methodological and policy reasons, Keynes favored directly employing the unemployed on a continuous basis via a permanent on-the-spot employment program. In recessions, a strong boost to demand and large-scale capital investment to absorb some of the unemployed was needed. As economies recovered and expanded, smaller and more targeted direct job creation programs for the unemployed in distressed areas would secure true full employment without fueling inflationary pressures or eroding the income distribution.

What type of jobs? Not the ditch-digging kind the profession has again mistakenly identified with the Keynes's solution. Could we not use more universities, local schools, recreation areas, theaters, museums, galleries, cafes, or dance halls, Keynes asked. He identified pressing needs to address at the time; almost a century later we can point to the same needs that wealthy and developed nations have: declining communities, crumbling infrastructure, inadequate public housing, environmental degradation. Public works, Keynes argued can be used to "replan the environment of our daily life... Not only shall we come to possess these excellent things, but...we can hope to keep employment good for many years to come" (Keynes 1980: 270). Some projects, such as large-scale housing programs, would require careful planning and organization, but some would be swift and inexpensive: "[T]o preserve the national domain for exercise and recreation and the enjoyment and contemplation of nature the cliffs and coastline of the country ... that requires nothing more than the decision to act" (Keynes 1980: 269).

\section{ANSWERING KEYNES'S CHALLENGE: POLICY DESIGN AND IMPLEMENTATION}

Keynes provided the blueprint for designing fiscal policy for full employment. Good intentions, he argued, were never the problem; lack of conviction and creativity were. Minsky and others answered the call. The Employer of Last Resort (Minsky 1986; Wray 1998), Buffer Stock Employment (Mitchell 1998), Full Employment through Social Entrepreneurship (Tcherneva 
2012c), Job Guarantee (Ginsburg 1997), Public Service Employment (Harvey 1989), and Green Jobs (Forstater 2004) proposals all provide program design that aims to secure full employment over the long run.

Much can be learned from direct job creation efforts around the world. There are very few programs that operate as long-run measures. Still, each has delivered socioeconomic, political, and environmental benefits in addition to their employment impact. The only program at the present time that is technically permanent is India's National Rural Employment Guarantee Act (NREGA). In 2005, it enshrined into law the access to a job as a basic human right - a right that was articulated by the United Declaration of Human Rights (1948). NREGA provides 100 days of paid employment at the statutory minimum wage in a community or rural project to any individual willing to work. Though the program is relatively young and the unemployment and poverty problems in India are immense, the program has already proved to be an important component of India's overall poverty alleviation strategy. A recent study indicates that it has also delivered important environmental benefits (Indian Institute of Science 2013).

Another recent large scale direct job creation program was Argentina's Plan Jefes $y$ Jefas. It was implemented as a crisis resolution measure in 2001 (much like the New Deal programs in the U.S. during the 30s), under popular demand for direct job creation programs. Plan Jefes guaranteed part-time employment at a minimum wage to any unemployed head of household. It delivered important benefits to beneficiaries, especially women who enrolled in the program in large numbers. It helped socialize their care burden and provided them income and assets. Some women used the program to launch their own businesses that supported them once the program ended. Poor women felt especially empowered by the program. Even when the Plan Jefes was being phased out and they were being encouraged to transfer to a conventional welfare program that provided income but without the requirement to work, in some cases poor women either refused to switch programs or, once they did, continued to go to their place of work so long as their Jefes project was still operating (for a detailed study of this program and impact on beneficiaries, see Tcherneva 2013).

South Africa is another country attempting to deal with its massive unemployment and poverty problems through direct job creation. The Expanded Public Works Programme was launched in 2004 and enlarged considerably in 2009. It is a government job creation initiative, 
which seeks to engage the poorest and most vulnerable individuals within South African society in effective combinations of paid work and training. Work provided through the program aims to fill the deficits in infrastructure and social and environmental services (Lieuw-Kie-Song 2009).

While in recent years, on-the-spot employment programs have primarily been embraced by developing nations, modern developed economies can benefit from the direct approach. After all, they too have failed to solve the problem of unemployment and continue to be plagued (in various degrees) by mass poverty, inadequate public services, languishing communities, and decrepit public spaces. A carefully designed direct job creation program in a developed nation can empower the burgeoning new social entrepreneurial sector to employ the unemployed for the public purpose (Tcherneva 2012c). The "new social economy" has deployed private resources to address social needs. It has helped propel sustainable agriculture practices, green technology, and environmental renewal. For example, initiatives that have aimed to address the "food desert" problem in the U.S. have generated the type of targeted jobs in distressed communities that Keynes called for. A permanent direct job creation program can scale up those and other initiatives by marrying the objectives of the individual social projects with the goal of providing employment for all who wish to work. This can be the new face of the Keynesian on-the-spot employment program for developed nations.

\section{CONCLUSION}

Consider the space engineer who has neither built nor launched a rocket, insisting that the moon is beyond reach. This is the state of affairs in economics today as it concerns the goal of full employment. Though Keynes provided a blueprint for a long-run full employment program, it has never been put in motion. We have several modern proposals that reinterpret this blueprint with a design that provides jobs for all who wish to work for the public purpose. Most of these proposals include important macroeconomic stabilization features that hold the promise of anchoring prices and improving the income distribution. Mainstream economists, by and large, have not considered the theoretical, empirical, or methodological merits of these contributions. It thus has no testable knowledge of the viability of securing tight full employment. The limited work on direct job creation around the world discussed above, has provided important insights 
into the benefits and challenges in implementing full employment programs over the long run. A scientific approach to full employment would require developing, implementing, testing, evaluating, and trouble-shooting these programs.

Two roads to full employment have been laid before us: 1) the pump priming, proinvestment, pro-growth approach of the Neoclassical Synthesis and the modern New Economic Consensus and 2) the permanent direct "on-the-spot" job creation program for all who want to work in a project that serves the public purpose found in the works of Keynes and his followers. One of these remains the road not taken. 


\section{REFERENCES}

Beveridge, W. H. (1944) Full Employment in a Free Society. London: Allen \& Unwin.

Eriksson, S. and Rooth, D.-O. (forthcoming) "Do Employers Use Unemployment as a Sorting Criterion When Hiring? Evidence from a field experiment," American Economic Review.

Forstater, M. (2004) "Green Jobs: Addressing the Critical Issues Surrounding the Environment, Workplace and Employment," International Journal of Environment, Workplace and Employment 1(1): 53-61.

Gordon, W. (1997) "Job Assurance: The Job Guarantee Revisited," Journal of Economic Issues 31(3): 826-834.

Harvey, P. (1989) Securing the Right to Employment, Princeton, NJ: Princeton University Press.

Indian Institute of Science (2013) Environmental Benefits and Vulnerability Reduction through Mahatma Gandhi National Rural Employment Guarantee Scheme, Bangalore, Karnataka.

Keynes, J.M. (1964[1936]) The General Theory of Employment, Interest, and Money, New York: Harcourt-Brace \& World, Inc.

. (1980) Activities 1940-46. Shaping the Post-War World: Employment and Commodities. Volume XXVII of Collected Works, D. Moggridge (ed.), London, UK: Macmillan.

. (1981) Activities 1922-29. The Return to Gold and Industrial Policy: Part II. Volume XIX of Collected Works, D. Moggridge (ed.), London, UK: Macmillan . (1982) Activities 1931-39. World Crises and Policies in Britain and America. Volume XXI of Collected Works, D. Moggridge (ed.), London, UK: Macmillan.

Krugman, P. (1999) The Return of Depression Economics, New York: W.W. Norton \& Company, Inc.

Lieuw-Kie-Song, M. (2009) "The South African Expanded Public Works Programme (EPWP) 2004-2014" Employment Guarantee Policies: Conference Proceedings, Levy Economics Institute, Annandale-on-Hudson, NY (June).

Minsky, H. P. (1986) Stabilizing an Unstable Economy, New Haven, CT: Yale University Press.

Mitchell, W. F. (1998) "The Buffer Stock Employment Model and the NAIRU: The Path to Full Employment," Journal of Economic Issues 32 (June): 547-556. 
Tcherneva, P. R. (2012a) “On-the-spot Employment: Keynes’s Approach to Full Employment and Economic Transformation," Review of Social Economy, 70 (1): 57-80.

. (2012b) "Inflationary and Distributional Effects of Alternative Fiscal Policies: An Augmented Minskian-Kaleckian Model.” Working Paper \#706. Levy Economics Institute, Annandale-on-Hudson, NY.

. (2012c) "Full Employment through Social Entrepreneurship: the Non- Profit Model for Implementing a Job Guarantee,' Policy Note 2012/1, Levy

Economics Institute, Annandale-on-Hudson, NY, (March).

Tcherneva, P. R. (2013) “Beyond Full Employment: What Argentina's Plan Jefes Can Teach Us about the Employer of Last Resort" in M. Forstater and M. Murray (eds.) The Job Guarantee: Toward True Full Employment, Palgrave.

Vickrey, W. S. (1994) "Why Not Chock-Full Employment," Atlantic Economic Journal, 22 (1), (March): 39-45

Weidner, J. and Williams, J. C. (2011) "What Is the New Normal Unemployment Rate?" FRBSF Economic Letter, Federal Reserve Bank of San Francisco, (February) http://www.frbsf.org/economic-research/files/el2011-05.pdf

Wray, L. R. (1998) Understanding Modern Money: The Key to Full Employment and Price Stability, Northampton, MA: Edward Elgar. 